\title{
ON THE SUSCEPTIBILITY OF THE DIFFERENT VARIETIES OF BIG-LEAFED TURNIP TO DAMAGE CAUSED BY CABBAGE MAGGOTS (Hylemyia spp.)
}

\author{
ANNA-LiISA VARIS \\ Department of Pest Investigation, Agricultural Research Centre, \\ Tikkurila
}

Received October 15th 1958.

The cabbage root fly (Hylemyia brassicae Bouché) and the turnip root fly (Hylemyia floralis Fall.) are the most important pests occuring in the crucifers in Finland. The larvae live in the underground parts of the plants burrowing channels in them and often causing considerable losses in yield. The abundance and severity of damage varies in different years, as well as in different species and varieties.

According to inquiries instituted in Sweden (1), the early varieties of the turnip were attacked more severely than the late ones, likewise the round ones more than the long ones. According to Morison (2), the hard varieties of the turnip and swede became less damaged than the soft ones. This is due to the ability of the former better to resist the aftereffect of affect, for the calculations done on the amounts of the pupae on the surface of the hard and the soft varieties have shown that the numbers are approximately equal. REICHELT (3) has on the basis of his investigations on red cabbage, concluded that susceptibility is not a characteristic of any specific variety, for although the distinct differences between the different varieties can be noted in a year their order varies to a notable degree in different years. SALONEN (4) states that according to his observations at Inari (lat. $69^{\circ} 5^{\prime} \mathrm{N}$ ) the roundish big-leafed turnips with dense foliage are distinctly more resistent against damage caused by the cabbage maggots than the flatround ones, as the root of the first is stouter and more amply branching. The larvae can easily cut through the thin root of the flat-round turnip and the plant withers.

In the years 1951-1955 the damage caused by the cabbage maggots to the different varieties of big-leafed turnip (Brassica rapa L. v. rapifera Metzg.) was studied at Tikkurila (lat. $60^{\circ} 20^{\prime} \mathrm{N}$ and long. $25^{\circ} 30^{\prime} \mathrm{E}$ ). The examinations were made on the varieties used in the field tests at the Agricultural Research Centre, Department of Plant Husbandry. A total of 200 turnips of each variety was examined. The varieties used in tests for several years will be examined first. The following varieties of big-leafed turnip were in general cultivation:

1. the so called "Nativen big-leafed turnip, purple topped, strap-leaved, and flat, from Holland (A. R. Zwaan \& Sohn, Voorburg), the seed of the variety is cultivated in Finland.

2. the White Dutch, strap-leaved and flat, from the same firm as the former.

3. the Green Globe, green topped, roundish and lobate from England (Charles Sharpe \& Co., Sleaford). 
The damage suffered by these varieties during $1951-1955$ is presented in Table 1. The number of damaged roots is given in percentages. The average extent of damage is also mentioned.

The damage varied considerably in different varieties during different years. For that reason no conclusions on the susceptibility of a variety to damage could be drawn on the basis of results of examinations obtained in one single year. The "Native" big-leafed turnip became damaged most severely in the years of investigation (the percentage of damage was 89 while the average of damage of all varieties was 80 ). For a period of two years the variety Sirius tetrapl. Svalöv was included in the test. This variety suffered distinctly slighter damage than the other varieties mentioned above (in 1954 the percentage of damage was 82 and the average of damage 1.6 , in 1955 the corresponding numbers were 65 and 0.9 ).

In the second variety test, in which the "Native» big-leafed turnip also was used as the standard, the following varieties were included in $1952-1955$ :

1. the Nativen big-leafed turnip.

2. Sirius Riesen, green-topped, round and lobate, from Holland (A. R. Zwaan \& Sohn, Voorburg).

3. Zwaans Brabo, purple-topped, fairly long, and strap-leaved, from the same firm as No. 2.

4. Zwaans Favoriet, purple-topped, fairly long, and lobate, from the same firm as the above.

5. Gelria, purple-topped, fairly long, and strap-leaved, from Holland (N. V. Sluis en Groot's, Enkhuizen).

6. Lincolnshire Red Globe, purple-topped, long-round, and lobate, from England (Hurst \& Son Ltd., London).

7. Purple Top Mammoth, form and origin as No. 6.

The damage to these species in different years is presented in Table 1 .

Table 1. Damage caused by cabbage maggots (Hylemyia spp) to the different varieties of the big-leafed turnip at Tikkurila in the years $1951-55$. Scale: $0=$ fully healthy, $5=$ fully damaged.

\begin{tabular}{|c|c|c|c|c|c|c|c|c|c|c|c|c|}
\hline \multirow[b]{2}{*}{ Variety } & \multicolumn{2}{|c|}{1951} & \multicolumn{2}{|c|}{1952} & \multicolumn{2}{|c|}{1953} & \multicolumn{2}{|c|}{1954} & \multicolumn{2}{|c|}{1955} & \multicolumn{2}{|c|}{ Average } \\
\hline & 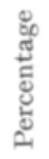 & 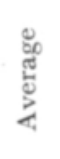 & 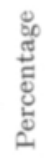 & 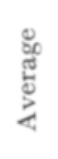 & 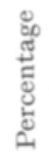 & 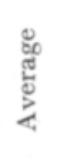 & 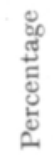 & 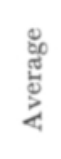 & 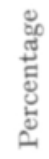 & 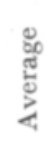 & 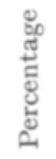 & 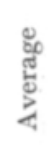 \\
\hline Natives & 80 & 1.0 & 89 & 1.8 & 82 & 1.3 & 99 & 1.9 & 96 & 1.8 & 89 & 1.6 \\
\hline White Dutch & 57 & 0.8 & 78 & 1.5 & 78 & 1.2 & 91 & 1.9 & 82 & 1.2 & 77 & 1.3 \\
\hline Green Globe & 51 & 0.6 & 80 & 1.6 & 62 & 1.0 & 93 & 2.4 & 91 & 1.5 & 75 & 1.4 \\
\hline Average & 63 & 0.8 & 82 & 1.6 & 74 & 1.2 & 94 & 2.1 & 90 & 1.5 & 80 & 1.4 \\
\hline Native & & & 77 & 1.6 & 87 & 1.3 & 96 & 1.8 & 94 & 1.8 & 89 & 1.6 \\
\hline Sirius Riesen & & & 76 & 2.0 & 71 & 1.2 & 95 & 2.0 & 81 & 1.3 & 81 & 1.6 \\
\hline Zwaans Brabo & & & 66 & 1.0 & 55 & 1.0 & 92 & 1.9 & 71 & 1.1 & 71 & 1.3 \\
\hline Zwaans Favoriet & & & 86 & 1.1 & 60 & 1.2 & 92 & 2.1 & 83 & 1.3 & 80 & 1.4 \\
\hline Gelria & & & 67 & 1.5 & 58 & 1.0 & 92 & 2.0 & 75 & 1.4 & 73 & 1.5 \\
\hline Lincolnsh. Red Globe & & & 82 & 2.0 & 65 & 1.2 & 93 & 2.2 & 85 & 1.6 & 81 & 1.8 \\
\hline Purple Top Mammoth & & & 91 & 2.3 & 75 & 1.4 & 96 & 2.2 & 85 & 1.7 & 87 & 1.9 \\
\hline Average & & & 78 & 1.6 & 67 & 1.2 & 94 & 2.0 & 82 & 1.5 & 80 & 1.6 \\
\hline
\end{tabular}


Variety 3 was damaged less than the others, the damage remaining below the average each year. Variety 7 shows the opposite tendency the damage being continually above the average. The number of damaged specimens of the "Native" big-leafed turnip was above the average in this group.

As the tests comprised turnips of different shapes, it is interesting to examine whether the shape of a turnip has any relation to the damage caused by the cabbage maggots. The material in this examination was considerably larger than that mentioned above, because also varieties used in tests for shorter periods were included. Since the tests did not comprise a sufficient number of turnips of each shape in all the years in question, the results are presented in two different groups (Table 2) in order to facilitate comparison. The total of 200 turnips of each test member was examined also here. In cases where the tests of the same year had the same sowing time and growing place or where the damage to the standards was equal in extent, the results of the trials have been combined. The varieties Sirius tetrapl. Svalöv and Petrovski Turnip have been excluded, because the damage to these varieties very distinctly deviates from the general level.

The flat and flat-round big-leafed turnips were examined in the course of two years and the damage was identical with that to the round big-leafed turnips in the same tests. Likewise the damage in the round big-leafed turnips included in the tests during five years was indentical with that in the long-round and fairly long turnips in the same tests.

Table 2. Damage caused by cabbage maggots (Hylemyia spp.) to big-leafed turnips of different shapes at Tikkurila in $1951-55$. Scale: $0=$ fully healthy, $5=$ fully damaged.

\begin{tabular}{|c|c|c|c|c|c|c|c|c|c|c|}
\hline \multirow{2}{*}{$\begin{array}{c}\text { Year } \\
1951\end{array}$} & \multicolumn{3}{|c|}{$\begin{array}{l}\text { The flat and flat-round } \\
\text { Number Percentage Average } \\
\text { of } \quad \text { of damage } \\
\text { varie- }\end{array}$} & \multirow{2}{*}{$\begin{array}{c}\begin{array}{c}\text { Number } \\
\text { of } \\
\text { varie- } \\
\text { ties }\end{array} \\
6\end{array}$} & \multicolumn{3}{|c|}{$\begin{array}{l}\text { The round } \\
\text { Percentage Average } \\
\text { of damage }\end{array}$} & \multicolumn{3}{|c|}{$\begin{array}{l}\text { The long-round and fairly long } \\
\text { Number Percentage Average } \\
\text { of } \quad \text { of damage } \\
\text { varie- }\end{array}$} \\
\hline & 5 & 61 & 0.8 & & 5 & 6 & 0.7 & & & \\
\hline " & 6 & 39 & 0.5 & 4 & 4 & 5 & 0.6 & & & \\
\hline 1952 & 19 & 70 & 1.3 & 22 & 7 & 1 & 1.5 & & & \\
\hline Average & & 57 & 0.9 & & 5 & 67 & 0.9 & & & \\
\hline 1951 & & & & 4 & 4 & 15 & 0.6 & 3 & 39 & 0.4 \\
\hline 1952 & & & & 22 & 7 & 1 & 1.5 & 11 & 78 & 1.6 \\
\hline 1953 & & & & 5 & 6 & 2 & 1.0 & 7 & 65 & 1.2 \\
\hline 1954 & & & & 4 & 9 & 3 & 2.1 & 5 & 93 & 2.1 \\
\hline 1955 & & & & 4 & 8 & 3 & 1.4 & 5 & 80 & 1.4 \\
\hline Average & & & & & 7 & 1 & 1.3 & & 71 & 1.3 \\
\hline
\end{tabular}


These tests show that the shape of the turnip does not seem to affect the susceptibility of the variety to damage caused by cabbage maggots; the damage was either slight or moderate. It is, however, obvious that in case the damage is severe the round and long-round varieties which generally have strong roots endure damage better and recover from it more quickly than the flat and flat-round varieties with thin roots. Thus the shape of the turnip may also be of importance in regard to the top yield.

\section{$S u m m a r y$}

Of all the varieties most generally cultivated in Finland (the "Native" bigleafed turnip, the White Dutch, and the Green Globe) the "Native» big-leafed turnip proved to be the most susceptible to damage caused by cabbage maggots. The damage suffered by the Sirius tetrapl. Svalöv variety included in the tests only for two years, was considerably slighter than in other varieties.

In the second test in which the varieties listed on page 272 were included for four successive years, the Zwaans Brabo was damaged least of all, the damage being below the average in every year investigated. As to the Purple Top Mammoth the damage was continually above the average. In this group, too, the number of the damaged specimens of the "Nativen big-leafed turnip was above the average.

The shape of the turnips (the material was grouped as follows: 1. the flat and flat-round, 2. the round, and 3. the long-round and fairly long turnips) did not seem to affect the extent of the damage caused by the cabbage maggots, not at any rate when the level of damage was slight or moderate as in the cases investigated. It is, however, obvious, that in cases of severe damage the round and longround varieties which generally have strong roots, endure damage better and recover from it more quickly than the flat and flat-round varieties with their thin roots.

\section{REFERENCES:}

(1) Lundblad, O. 1933. Kålflugorna. Stat. växtskyddsanst. med. 3: 1-103.

(2) Morison, G. D. 1938. The Turnip Root Fly (Phorbia floralis Fallen) in Northern Scotland. Verh. VII intern. Kongr. Ent., Berlin 1938, p. 2576-2584.

(3) Reichelt, K. 1930. Achtet auf die Kohlmade. Hannoversche land. u. forstw. Ztg 83: $394-395$. (Ref. Tomaszewski \& Nitsche \& Langenbuch 1934).

(4) SALONEN, A. 1954. Ristikukkaisten tuholaisista ja niiden torjunnasta Tunturi-Lapin alueella. Koet. ja käyt. 6: 22.

(5) Tomaszewski, W. \& Nitsche, G. \& Langenbuch, R. 1934. Die Bekämpfung der Kohlfliegen Chorthophila brassicae Bché und Ch. floralis Fall. Arb. Phys. angew. Ent. 1: 229-242, $280-290$. 
S E L O T U S :

ERI NAATTINAURISKANTOJEN ALTTIUDESTA KAALIKÄRPÄSTOUKKIEN (Hylemyia spp.) AIHEUTTAMALLE VIOITUKSELLE.

\author{
ANNA-LIISA VARIS
}

Tuhoeläintutkimuslaitos, Tikkurila

Vuosina 1951-55 tutkittiin Tikkurilassa kaalikärpästen aiheuttamaa vioitusta eri naattinauriskannoissa. Eri vuosina vioitus vaihteli tuntuvasti eri kannoissa, minkä vuoksi yhden vuoden tarkastustulosten perusteella ei voida tehdä johtopäätöksiä jonkin kannan alttiudesta kaalikärpäsvioitukselle. Tässä esitettyinä vuosina oli maassamme yleisimmin viljellyistä naattinauriskannoista ("kotimainen naattinauris, Valkea hollantilainen ja Green Globe) skotimainen naattinauris alttein kaalikärpäsvioitukselle. Kahtena vuonna kokeessa olleessa kannassa Sirius tetrapl. Svalöv vioitus oli tuntuvasti vähäisempi kuin muissa kannoissa.

Toisessa kantakokeessa (kannat on lueteltu sivulla 272) vioittui vähiten Zwaans Brabo, jossa vioitus jokaisena neljänä koevuonna jäi keskimääräistä vioitusta vähäisemmäksi. Kannassa Purple Top Mammoth taas vioitus oli jatkuvasti keskimääräistä runsaampaa. Tässäkin ryhmässä oli »kotimaisessa» naattinauriissa keskimääräistä enemmăn vioittuneita.

Nauriiden muodolla (aineisto oli ryhmitelty seuraavasti: 1. litteät ja litteänpyöreät, 2. pyöreät ja 3. pitkänpyöreăt ja pitkähköt nauriit) ei näyttänyt olevan vaikutusta siihen, miten altis jokin kanta on kaalikärpäsvioitukselle; vioitus oli lievää tai kohtalaista. On kuitenkin ilmeistä, että vioituksen ollessa ankara pyöreät ja pitkänpyöreăt kannat, jotka yleensä ovat voimakasjuurisia, kestävät vioitusta paremmin ja toipuvat siitä nopeammin kuin ohutjuurisemmat litteät ja litteänpyöreät kannat. Tăten saattaa nauriiden muoto vaikuttaa myős naattisadon măårän. 